\title{
ACUTE CHANGES IN SERUM UREA, URIC ACID AND CREATININE IN HEALTHY YOUNG ADULTS AFTER MODERATE EXERCISE
}

\author{
Anubhav Dwivedi' ${ }^{1}$ Manju Lata Arya ${ }^{2}$, Qazi Rais Ahmed ${ }^{3}$
}

${ }^{1}$ Assistant Professor, Department of Physiology, Rama Medical College Hospital and Research Centre, Mandhana, Kanpur, Uttar Pradesh, India.

${ }^{2}$ Associate Professor, Department of Physiology, Rama Medical College Hospital and Research Centre, Mandhana, Kanpur, Uttar Pradesh, India.

${ }^{3}$ Professor and HOD, Department of Physiology, Rama Medical College Hospital and Research Centre, Mandhana, Kanpur, Uttar Pradesh, India.

\begin{tabular}{l}
\hline ABSTRACT \\
BACKGROUND \\
Effects of exercise on lipid profile of blood have been studied in many studies but studies to evaluate the exercise on blood indicators \\
of renal functions are few. \\
The aim of this study was to investigate the acute changes in serum urea, uric acid and creatinine in young healthy adults after \\
single bout of moderate exercise.
\end{tabular}

\section{MATERIALS AND METHODS}

This uncontrolled clinical trial study was cleared by ethical committee of institution and total 79 untrained subjects (51 males, 28 females) of age group 18 to 35 yrs., participated in the study. Subjects were explained about study and gave written informed consent. Detailed information regarding dietary habits, any addiction, illness, medication was taken. After physical examination, blood samples were collected before exercise. Single bout of exercise by cyclometer for 30 minutes was done, and blood samples were taken after exercise along with physical examination. Serum levels of urea, uric acid and creatinine were analysed by auto analyser VITA LAB SELECTRA E. Data was collected and assessed by student ' $t$ ' test and $p$-value $<0.05$ was taken as significant.

\section{RESULTS}

Pre and post exercise levels of urea $(29.13 \pm 4.73,31.17 \pm 4.75 \mathrm{mg} / \mathrm{dl})$, uric acid $(5.04 \pm 0.94,5.40 \pm 1.01 \mathrm{mg} / \mathrm{dl})$ and creatinine $(0.82$ $\pm 0.05,0.84 \pm 0.12$ ) were measured. Statistical significance was observed between pre and post exercise levels of serum urea, uric acid and creatinine in males though no significant difference was noted in female subjects.

\section{CONCLUSION}

Further studies are needed to investigate the exercise induced changes in biochemical parameters of renal functions in larger groups.

\section{KEY WORDS}

Blood, Creatinine, Urea, Uric Acid, Exercise.

HOW TO CITE THIS ARTICLE: Dwivedi A, Arya ML, Ahmed QR. Acute changes in serum urea, uric acid and creatinine in healthy young adults after moderate exercise. J. Evolution Med. Dent. Sci. 2019;8(01):73-75, DOI: 10.14260/jemds/2019/16

\section{BACKGROUND}

Physical activity is essential for good health, prevention of diseases and good quality of life. Benefits of exercise training also lies in improving blood biochemistry and various parameters of cardiac activity. Epidemiological studies have suggested that regular physical activities are associated with reduced incidence of coronary heart disease and cerebrovascular accidents.

It is postulated that during exercise blood pressure rises and its flow falls ${ }^{1}$ which leads to disruption in glomerular filtration and reabsorption.

'Financial or Other Competing Interest': None.

Submission 27-11-2018, Peer Review 20-12-2018,

Acceptance 29-12-2018, Published 07-01-2019.

Corresponding Author:

Dr. Manju Lata Arya,

Room No. 204, Accommodation 2,

Rama Medical College Hospital and

Research Centre,

Mandhana, Kanpur-209217,

Uttar Pradesh, India.

E-mail:manjulataarya77@yahoo.co.in

DOI: $10.14260 /$ jemds/2019/16
This might be reflected in blood urea nitrogen compounds concentration suggesting physiological changes in kidneys. There are other factors that affect serum creatinine concentration particularly muscle mass, consumption of cooked meat. Similarly exercise has been suggested as factor for protein catabolism to raise the urea production and creatinine level. ${ }^{2}$

There are various studies about exercise induced protein hematuria, proteinuria and acute renal failure following marathon,3,4 but studies investigating the effect of sub maximal exercise on indicator of renal function are few. This study was done to evaluate this aspect of sport physiology by measuring serum levels of creatinine, urea, uric acid after single bout of moderate exercise in healthy young adults.

\section{MATERIALS AND METHODS}

This Uncontrolled clinical trial study was done in G.S.V.M. Medical College Kanpur and was cleared by ethical committee of college. Individuals with history of any illness or any cause leading to alteration in biochemical parameters were excluded in random selection. Subjects with routine exercise activities were also not included. Tota 179 young healthy adults in age group of 18 to 35 years ( 51 males and 28 females) were 
selected. They were explained about study and informed written consent was taken.

Detailed information was collected through careful history taking regarding age, gender, any addiction, medication etc. Height, weight were taken for calculation of BMI (Weight in Kg / height in meter $^{2}$ ) was done and subjects were classified in categories of underweight $(<18.5 \mathrm{~kg} / \mathrm{m} 2)$ normal $(18.5-24.5$ $\mathrm{kg} / \mathrm{m} 2$ ), overweight (25-30 kg/m2), and obese (> $30 \mathrm{~kg} / \mathrm{m} 2)$. Respiratory rat, pulse rate were recorded. Blood pressures were measured by auscultatory method with sphygmomanometer. Blood samples were taken from antecubital vein. Biochemical parameters serum urea, uric acid, creatinine were measured before introducing exercise. All biochemical estimations were done by Biochemical Autoanalyser VIT A LAB SELECTRA E in department of biochemistry and pathology.

Participants were instructed about the exercise. Single bout of acute exercise of moderate grade (Heart rate 100-125 beats/ minutes) by cyclo ergometer was done for period of 30 minutes under supervision. After stoppage of exercise physical parameters such as pulse rate, respiratory rate and B.P. were reassessed. Blood samples were recollected and analysis was done for previously mentioned parameters.

\section{Statistical Analysis}

Statistical analysis was done using the software SPSS version 21. Mean of Pre-test scores and Post-test scores for all the parameters were compared using Paired samples t-test. Cognitive gain was calculated as Post-test score minus Pre-test score. For all statistical evaluations, probability of value $<0.05$ was considered significant.

\section{RESULTS}

\begin{tabular}{|c|c|c|c|c|c|c|}
\hline \multirow{2}{*}{$\begin{array}{c}\text { BMI } \\
\left(\mathbf{k g} / \mathbf{m}^{\mathbf{2}} \mathbf{)}\right.\end{array}$} & \multicolumn{2}{|c|}{ Male } & \multicolumn{2}{c|}{ Female } & \multicolumn{2}{c|}{ Total } \\
\cline { 2 - 7 } & $\mathbf{N o}$ & $\mathbf{\%}$ & No & $\mathbf{\%}$ & No & $\mathbf{\%}$ \\
\hline$<18.5$ & 10 & 7 & 17 & 8.86 & 17 & 21.51 \\
\hline $18.5-\leq 24.5$ & 25 & 14 & 39 & 17.72 & 39 & 49.36 \\
\hline$>24.5-30$ & 10 & 4 & 14 & 5.06 & 14 & 17.72 \\
\hline$>30$ & 6 & 3 & 9 & 3.79 & 9 & 11.39 \\
\hline Total & $\mathbf{5 1}$ & $\mathbf{6 4 . 5 5}$ & $\mathbf{2 8}$ & $\mathbf{3 4 . 4 5}$ & $\mathbf{7 9}$ & $\mathbf{1 0 0}$ \\
\hline
\end{tabular}

Table 1. Distribution of Subjects According to Gender and $B M I\left(\mathrm{~kg} / \mathrm{m}^{2}\right)$

Approximately $50 \%$ of participants had BMI of normal range while $21.51 \%$ were underweight. About $29 \%$ of subjects were either overweight or obese according to their BMI.

\begin{tabular}{|c|c|c|c|}
\hline \multicolumn{4}{|c|}{ Male } \\
\hline Parameter & & Mean \pm SD & P Value \\
\hline \multirow{2}{*}{$\begin{array}{c}\text { Heart rate } \\
\text { beats/minute }\end{array}$} & Pre exercise & $77.19 \pm 9.45$ & \multirow{2}{*}{$\mathrm{p}>0.05$} \\
\hline & Post exercise & $128 \pm 8.56$ & \\
\hline \multirow{2}{*}{$\begin{array}{l}\text { Respiratory rate } \\
/ \text { min }\end{array}$} & Pre exercise & \begin{tabular}{|l|}
$15.21 \pm 3.34$ \\
\end{tabular} & \multirow{2}{*}{$\mathrm{p}>0.05$} \\
\hline & Post exercise & $26.88 \pm 5.23$ & \\
\hline \multirow{2}{*}{$\begin{array}{c}\text { Systolic } \\
\mathrm{BP}(\mathrm{mmHg})\end{array}$} & Pre exercise & $117.8 \pm 7.67$ & \multirow{2}{*}{$\mathrm{p}>0.05$} \\
\hline & Post exercise & $132.6 \pm 8.72$ & \\
\hline \multirow{2}{*}{$\begin{array}{l}\text { Diastolic BP } \\
\text { (mmHg) }\end{array}$} & Pre exercise & $78.8 \pm 7.50$ & \multirow{2}{*}{$\mathrm{p}>0.05$} \\
\hline & Post exercise & $103.2 \pm 12.72$ & \\
\hline \multicolumn{4}{|c|}{$\begin{array}{c}\text { Table 2. Mean of Heart Rate, Respiratory Rate, and Blood } \\
\text { Pressure in Males }\end{array}$} \\
\hline
\end{tabular}

\begin{tabular}{|c|c|c|c|}
\hline \multicolumn{4}{|c|}{ Female } \\
\hline Parameter & & Mean \pm SD & P Value \\
\hline \multirow{2}{*}{$\begin{array}{c}\text { Heart rate } \\
\text { beats/minute }\end{array}$} & Pre exercise & $80.13 \pm 8.23$ & \multirow{2}{*}{$\mathrm{p}>0.05$} \\
\hline & Post exercise & $130.45 \pm 7.67$ & \\
\hline \multirow{2}{*}{$\begin{array}{l}\text { Respiratory rate } \\
\text { /min }\end{array}$} & Pre exercise & $14.85 \pm 5.87$ & \multirow{2}{*}{$p>0.05$} \\
\hline & Post exercise & $23.64 \pm 5.46$ & \\
\hline \multirow{2}{*}{$\begin{array}{c}\text { Systolic } \\
\text { BP(mmHg) }\end{array}$} & Pre exercise & $115.8 \pm 8.76$ & \multirow{2}{*}{$\mathrm{p}>0.05$} \\
\hline & exercise & $136.6 \pm 7.97$ & \\
\hline \multirow{2}{*}{$\begin{array}{c}\text { Diastolic BP } \\
(\mathrm{mmHg})\end{array}$} & Pre exercise & $76.8 \pm 7.43$ & \multirow{2}{*}{$\mathrm{p}>0.05$} \\
\hline & Post exercise & $108.4 \pm 10.84$ & \\
\hline
\end{tabular}

Table 2 and 3 are showing variations in heart rates, respiratory rates and blood pressure in males and females before and after exercise. Changes were statistically insignificant in both the groups.

\begin{tabular}{|c|c|c|c|}
\hline \multicolumn{4}{|c|}{ Male } \\
\hline Parameter & & Mean \pm SD & P Value \\
\hline \multirow{2}{*}{$\begin{array}{l}\text { Serum Urea } \\
(\mathrm{mg} / \mathrm{dl})\end{array}$} & Pre exercise & $29.13 \pm 4.73$ & \multirow{2}{*}{$<0.001$} \\
\hline & Post exercise & $31.17 \pm 4.75$ & \\
\hline \multirow{2}{*}{$\begin{array}{l}\text { Serum Creatinine } \\
(\mathrm{mg} / \mathrm{dl})\end{array}$} & Pre exercise & $0.82 \pm 0.05$ & \multirow{2}{*}{$>0.05$} \\
\hline & Post exercise & $0.84 \pm 0.12$ & \\
\hline \multirow{2}{*}{$\begin{array}{c}\text { Serum Uric acid } \\
(\mathrm{mg} / \mathrm{dl})\end{array}$} & Pre exercise & $5.04 \pm 0.94$ & \multirow{2}{*}{$<0.001$} \\
\hline & Post exercise & $5.40 \pm 1.01$ & \\
\hline $\begin{array}{r}\text { Table 4. Cor } \\
\text { Pre anc }\end{array}$ & 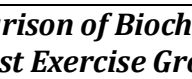 & al Dara & re $i$ \\
\hline
\end{tabular}

Highly statistically significant $(\mathrm{p}<0.001)$ difference were observed between pre and post exercise blood urea and uric acid levels of the males. No statistically significant difference was noted in serum creatinine level in males.

\begin{tabular}{|c|c|c|c|}
\hline \multicolumn{4}{|c|}{ Female } \\
\hline Parameter & & Mean \pm SD & P Value \\
\hline \multirow{2}{*}{$\begin{array}{c}\text { Serum Urea } \\
(\mathrm{mg} / \mathrm{dl})\end{array}$} & Pre exercise & $28.83 \pm 4.78$ & \multirow{2}{*}{$>0.05$} \\
\cline { 2 - 3 } & Post exercise & $30.48 \pm 4.69$ & \\
\hline $\begin{array}{c}\text { Serum Creatinine } \\
(\mathrm{mg} / \mathrm{dl})\end{array}$ & Pre exercise & $0.80 \pm 0.05$ & \multirow{2}{*}{$>0.05$} \\
\cline { 2 - 3 } & Post exercise & $0.82 \pm 0.07$ & \\
\hline $\begin{array}{c}\text { Serum Uric acid } \\
(\mathrm{mg} / \mathrm{dl})\end{array}$ & Pre exercise & $3.92 \pm 0.45$ & \multirow{2}{*}{$>0.05$} \\
\cline { 2 - 3 } & Post exercise & $4.02 \pm 0.53$ & \\
\hline \multicolumn{3}{|c|}{$\begin{array}{c}\text { Table 5. Comparison of Biochemical Parameters in } \\
\text { Pre and Post Exercise Group Among Females }\end{array}$} \\
\hline
\end{tabular}

No statistically significant $(p>0.05)$ difference were observed between pre and post exercise blood urea, creatinine and uric acid levels of females.

\section{DISCUSSION}

The positive effects of exercise on long term are known to lower the incidence of coronary artery disease, obesity, hypertension etc. For good health and better life quality changes in sedentary life style and exercise is recommended by physicians. Depending upon intensity and duration of exercise variations in physical parameters as well as biochemical results are expected. ${ }^{3}$

In 1996 Hubner-Wozniak et al reported changes in the blood nitrogen compounds concentrations in physical exercise. ${ }^{5}$ Jansen et al (1989) documented that enhanced protein catabolism is seen in prolong strenuous exercise. 6 Dudzinska et al (2001) have explained in their study how progressive hypoxia results in impairment of the oxidative resynthesis of ATP and increased degradation of purine 
nucleotides exercise with increasing intensity leads to increased concentration of uric acid. ${ }^{7}$ Alina Gailiūnienè reported exercise-induced statistically insignificant $(p>0.05)$ increases in the blood parameters of nitrogen compounds (Creatinine, urea, total protein and uric acid) and suggested that it could be due to the common phenomenon of the physical stress and catecholamine effects. ${ }^{8}$ In this present study there is significant difference between urea and uric acid level in pre and post exercise conditions in males although in females no significant alteration seen in pre and post exercise levels. Significant change in levels of uric acid after exercise program in middle age females is reported by Bijeh $\mathrm{N}$ et al. ${ }^{9}$ Some of the studies, $10,11,12$ also reported increase in uric acid where as other studies ${ }^{11}$ have opposite observations.

Vanita Lal et al observed increase in creatinine level due to aerobic exercises in absence of renal damage.13 On the contrary Lippi $\mathrm{G}$ et al reported decreased concentration of serum creatinine in post exercise samples of endurance athletes. ${ }^{14}$ Slightly raised levels of creatinine were observed in this study but difference was insignificant in both males and females.

\section{CONCLUSION}

During physical activity, haemodynamic changes occur in kidneys and these changes might be reflected in blood content of nitrogen compounds. While doing interpretation of lab results, physiological effects of exercise should be taken in account. Physicians should take into account the effects of exercise of different intensities in patients especially of renal disorders. Further studies are needed to study the effects of exercise on blood chemical composition and kidney functions in a larger sample.

\section{REFERENCES}

[1] Poortmans JR, Vanderstraeten J. Kidney function during exercise in healthy and diseased humans. An update. Sports Medicine 1994;18(6):419-37.

[2] Poortmans JR, Haggenmacher C, Vanderstraeten J. Postexercise proteinuria in humans and its adrenergic component. Journal of Sports Medicine and Physical Fitness 2001;41(1):95-100.

[3] Ayca B, Sener A, Rabus AS, et al. The effect of exercise on urinary gamma-glutamyl transferase and protein levels of volleyball players. The Journal of Sports Medicine and Physical Fitness 2006;46(4):623-7.

[4] Stewart PJ, Posen GA. Case reports: acute renal failure following a marathon. The Journal of Physiology and Sports Medicine 1980;8(4):61-4.
[5] Hübner-Wozniak E, Lutoslawska G, Sendecki W, et al. Effects of a 10 week training on biochemical and hematological variables in recreational body builders. Biology of Sport 1996;13(2):105-12.

[6] Janssen GM, Degenaar CP, Menheere PP, et al. Plasma urea, creatinine, uric acid and total protein concentration before and after 15-, 25- and 42-km contests. International Journal of Sports Medicine 1989;10(Suppl 3):S132-S8.

[7] Dudzinska W, Lubkowska A, Dolegowska B, et al. Adenine, guanine and pyridine nucleotides in blood during physical exercise and restitution in healthy subjects. Eur J Appl Physiol 2010;110(6):1155-62.

[8] Gailiūnienè A, Stasiulis A, Michailovienè J. The effect of submaximal exercise on blood creatinine, urea, total protein and uric acid levels of trained and untrained subjects. Ugdymas, Kunokultura, Sportas $\mathrm{Nr}$ 2007;3(66):5-10.

[9] Bijeh N, Farahati S. The effect of six months of aerobic training on renal function markers in untrained middle aged women. International Journal of Sport Studies 2013;3(2):218-24.

[10] Dehghani M, Shemshaki H, Eshaghi MA, et al. Diagnostic accuracy of preoperative clinical examination in upper limb injuries. The Emerg Trauma Shock 2011;4(4):4614.

[11] Brites FD, Evelson PA, Christiansen MG, et al. Soccer players under regular training show oxidative stress but an improved plasma antioxidant status. Cinical Science (Lond) 1999;96(4):381-5.

[12] Lamina S, Okoye CG. Effect of low intensity continuous training programme on serum uric acid non pharmacological management of hypertension: a randomized controlled trial. Niger J Med 2010;19(1):77-86.

[13] Lal V, Raj A, Bhandari B. Chronic effects of aerobic and resistance exercise on cardio-metabolic profile in healthy non-obese. International Journal of Clinical and Experimental Physiology 2014;1(3)200-4.

[14] Lippi G, Brocco G, Franchini M, et al. Comparison of serum creatinine, uric acid, albumin and glucose in male professional endurance athletes compared with healthy controls. Clinical Chemistry Lab Med 2004;42(6):644-7. 